\title{
Barriers to Implement Green ICT in Bangladesh: A Study on Organizations
}

\author{
Ferdous Ara \\ Lecturer, Department of Computer Science \& Engineering \\ BGC Trust University Bangladesh
}

\begin{abstract}
Global warming and other environmental issues along with excessive use of energy are becoming the world's major concerns and need to be solved. The partial solution can be achieved by using eco-friendly technology in a country. Many countries have already taken proper initiatives to implement Green ICT at organizations. This paper presents the barriers in implementation of Green ICT at different organizations based on survey conducted in Bangladesh. After extensive studies on Green ICT, eight barriers are outlined. Survey questionnaire is used to measure the perception of the employees towards the hurdle of execution of Green ICT at organizations. Descriptive statistics is used to find the percentage of opinion of the respondents in different identified barriers. Moreover, t-test has been employed to identify whether the identified barrier are statistically significant or not. The survey revealed that lack of government strict regulation act, indifferent to arrange workshop and lack of trained manpower are important barrier in implementation of Green or sustainable ICT in organizations.
\end{abstract}

\section{General Terms}

Green ICT, Sustainability

\section{Keywords}

Green ICT, Organization, Barrier of Green ICT, Sustainable Development

\section{INTRODUCTION}

ICT is playing an important role in organizations. Its use in several organizations in the world in where there is high demand for electronic equipment. Electricity is a high contributor to climatic change. The coal or oil that helps generate it does releases carbon dioxide, and pollutants into the atmosphere. Going green is not an option. There are green ICT technologies in the market. But they are not bearing result by breaking barriers to implementation of Green ICT in organization. It's a key need to educate all employees of an organization about the Green ICT. It is very essential to identify the barriers in implementation of Green ICT practices at organization.

The interest of this research on Green ICT is to environmental protection by more eco-friendly in actions and decisions in organizations. Now many organizations focus on resource efficiency, and reduction of e-waste and emissions which will lead to improve environmental performance. The success of eco-innovation, sustainable development, and environmental friendliness become a major social phenomenon which is supported by government and different private organizations by regulatory agencies. Moreover, at present environmental concerns which are considered the most innovative have influenced the field of green information and communication technologies (ICT). Green ICT can play a positive role through energy efficiency in production and recycling of the used product. Eco-friendly production and use of different environment friendly products to minimize the environmental effect are nowadays having important factors for an organization. Based on these reflections, the influence in organizations to select ICT products and services with minimal negative environmental influences is important issue. This study attempts to identify which factors are barrier to adopt of green ICT in organizations. This will help the proper authority to take steps to implement Green ICT strategies.

\section{GREEN ICT IN ORGANIZATIONS}

Green Information and Communication Technology is broadly understood as an initiative to encourage individuals, groups, stakeholders and organization engaged in the use of ICT to consider environmental problems and find solutions to them [1]. Green ICT has an aspect of innovation in managing ICT related to the environment. From the viewpoint of an organization it makes sense to think about Green ICT as the direct impact of ICT on the environment. Green ICT is also linking with cost efficiency, making it good for the environment. The term Green ICT indicates the environment protection which involves with the growth of hardware and software with negligible influence on the environment or improving the existing ones and using ICT for diagnosing and solving environmental problems which targeted to reduce the negative effects of ICT usage on the environment for development and usage of applications dedicated to environmental protection.

To practice Green ICT, some of the organizations introduced environmental management practices (EMPs). These practices include environmental audits, total cost accounting, total quality management, pollution prevention plans, environmental training for employees, life cycle analysis, research and development (R\&D), and environmental standards for suppliers, and employee incentive programs for environmental suggestions [2]. There are many benefits that directly or indirectly involved in green ICT development and implementation in organizations or their usage by individuals.

\section{LITERATURE REVIEW}

Barriers that for Green ICT adoption may include affordable and accessible green ICT hardware, human skill and training, lack of awareness, lack of funding, policy of education systems, legal framework, lack of consumer demand, and lack of strategic decision-making process in organizations. With the increasing awareness of environmental issues around the world, organizations are turning to green ICT initiatives more and more. Not only are there significant environmental benefits to these initiatives, but they can also yield substantial business benefits. Under Green ICT, different organizations have aims to use computer by following four complementary paths such as Green use, Green disposal, Green design and Green manufacturing arises. For modern companies Green ICT is what analysts, manufacturers and providers call all IT solutions that save energy at business organizations. These 
include hardware, software and services. Green ICT trends are characterized to using ICT more efficiently and effectively to tackle environmental issues. Stark and Connolly [3] summarizes the benefits of utilizing Green ICT for businesses as it (1) helps businesses to reap the benefits of greener practices; (2) meets carbon reporting and reduction requirements; (3) saves operating expenses; (4) enhances the company's brand image and (5) increases stakeholder's value. Green ICT practices in most countries are quite rudimentary leaving room for improvement. However, United Kingdom (UK) has topped the list for being one of the first countries to focus on Green ICT including the UK HEI sector [4].

Green ICT involves business innovative practices that enhance the recognition of organizational situations [5] and a company's adaptation to the external dynamics with the use of IT [6], and ICT organizational impact where ICT supports business and vice versa [7]. The greatest benefit of green ICT to the universe and any nation is the reduced environmental impact and to individual as well as business is cost savings [8]. The recognition by organizations that greening their operations is not a cost of doing business but rather it can be a means by which organizations can be able to lower the cost of production will push many firms to adopt green ICT [9]. The Organization for Economic Cooperation and Development (OECD) has published a survey of government initiatives on Green ICT which concludes that initiatives tend to concentrate on the greening ICT's [10]. The government has a significant role to play in promoting green and cool ICT policies and initiatives against environmental concerns including Green house Gas emissions reductions [11]. When Microsoft implemented Greener IT practices inside company and it was result a $27 \%$ drop in the amount of power used by managed desktop computers as well as project costs saving of $\$ 12$ to $\$ 14$ per computer per year [12]. The decision to adopt green ICT depends on the expected benefits and investments. This decision depends on costs, competitiveness, financial support, managers and employees' characteristics and skills, legal regulations, supply, and demand [13]. In the last few decades, many projects have applied ICT systems to numerous fields, including the environmental monitoring at organizations. Well-designed ICT systems have the potential to examine related number of different devices, products, tools, services, and technologies, which not only improve monitoring, but also enhance strategy in management. Green ICT assists the reuse of energy flows across organization resulting to a more supply efficient creation system and less adverse environmental effects.

Presently a few number of IT based organizations merged Green strategies with their business process and some of them have found benefits from this merging. Jan [14] found that there is a gap in understanding how Green IS initiatives and strategies can be effectively integrated in IT based organizations.

\section{CONSTRAINTS TO IMPLEMENT GREEN ICT}

In the last few years global warming and climate change are the important issues in the front of society and become a common subject of discussion in global society. Green ICT also encourages and supports Greener behavior by the citizens of a country. By various means, including awareness campaigns and ongoing education, and in some cases legislation, the whole culture of any organizations can be changed. There is urgent need for organizations to inculcate sustainability in both its mission and vision statement. The Green ICT policy helps to comply with the environmental laws and government regulation and acts as a guideline for successful implementation of green practices.

The constraints that act as barriers in implementation of Green ICT are identified are listed out in table 1.

Table 1. Barriers for GICT implementation at Organization in Bangladesh

\begin{tabular}{|l|l|}
\hline $\begin{array}{l}\text { Sr. } \\
\text { No. }\end{array}$ & Particulars of Barrier \\
\hline 1. & $\begin{array}{l}\text { Lack of update knowledge of rapid changes of } \\
\text { technology }\end{array}$ \\
\hline 2. & Lack of motivation among employees \\
\hline 3. & Lack of government strict regulation for Green ICT \\
\hline 4. & Lack of proper plan for green ICT implementation \\
\hline 5. & No Budget allocation for implementing green ICT \\
\hline 6. & Indifferent for ICT workshops to update knowledge \\
\hline 7. & Lack of skilled or trained manpower \\
\hline 8. & Lack of research \& development activities \\
\hline
\end{tabular}

By examination of various constraints, the study only considered some of them mentioned above as a major hurdle for the success of Green practices implementation. The Green ICT as a vital area is only now starting to resonate with administrative people. The hidden energy costs, many times, the administration has no clue how much energy their operations are consuming as well as they may not even keen to know electricity bill of consumed energy cost. However no formal mandate is a good excuse for not acting.

\section{METHODOLOGY}

This paper tries to investigate barriers in Green ICT implementation at organizations. For this reason, the methodology of this paper employed survey based investigation techniques by employing Likert scales for obtaining insight in the perceptions and attitudes of the respondents towards implementing Green ICT at organizations. The primary data is collected from the employees of different organizations in Bangladesh. A structured questionnaire is developed to analyze evolution and barriers of Green ICT implementation. A questionnaire is used to collect data from 150 respondents from 10 organizations in Bangladesh. The respondents consisted of 20 from Top level managers, 30 ICT technical human resource, 50 Officers, and 50 Stuffs. The design of questionnaire is based on Liker five-point scaling method. Primary data were obtained through a survey. A statistical software (SPSS, version-20.0) has been used to examine the responses of survey questionnaire. Descriptive statistics along with test of hypothesis has used to identify whether different barriers of implementation Green ICT were statistically significant or not.

The hypothesis for our work is as follows:

$\mathrm{H}_{0}$ : Barriers for adopting Green ICT policy are not statistically significant

The further section provided detailed analysis of hypothesis testing.

\section{RESULTS AND ANALYSIS}

The study started with an interview of employees of various organizations with regard to barriers towards implementing green ICT. The identified barriers were then converted into questionnaires. According to the question respondents asked to respond to them. This section focused on Top level managers, ICT technical human resource, Officers, and 
Stuffs' responses on barriers of Green ICT implementation at organization.

\subsection{Barriers of Green ICT}

All the participants are asked about their opinion on the barriers of Green ICT i.e. lack of motivation and rational for adopting green policies. For statistical analysis the data is coded like Strongly Agree = 5, Agree $=4$, Partially Agree $=3$, Disagree $=2$ and Strongly Disagree $=1$. The responses collected from all respondent on the barrier and cumulative analysis of the same is described in Table 2 and shown in Fig 1 .

The table indicates that 53 percent respondents are strongly considered that lack of update knowledge of rapid changes of technology might the barrier to implement Green ICT while only 11.3 percent are disagreeing with the statement. The second question is important factor in an organizations ability to motivate employees to create Green ICT environment. 86.67 percent respondents are at least agreed that lack of motivation is the barrier to create Green ICT environment.

The study observed that strict government legislation is crucial for successful implementation of Green ICT in an organization and this is supported by 97.33 percent respondents. Moreover, 92.67 percent respondents' opined that lack of proper plan is a barrier for Green ICT. Furthermore, budget constraint is also hurdle to implement Green ICT.

Table 2: Barrier for GICT implementation at organizations: All Responses

\begin{tabular}{|c|c|c|c|c|c|c|c|}
\hline $\begin{array}{l}\text { Barriers to implement } \\
\text { Green ICT }\end{array}$ & $\begin{array}{l}\text { Strongly } \\
\text { Agree }\end{array}$ & Agree & $\begin{array}{l}\text { Partially } \\
\text { Agree }\end{array}$ & Disagree & $\begin{array}{l}\text { Strongly } \\
\text { Disagree }\end{array}$ & $\begin{array}{l}\text { Weighted } \\
\text { Average }\end{array}$ & Rank \\
\hline $\begin{array}{l}\text { Lack of update knowledge of } \\
\text { rapid changes of technology }\end{array}$ & $\begin{array}{c}80 \\
(53 \%) \\
\end{array}$ & $\begin{array}{c}33 \\
(22 \%) \\
\end{array}$ & $\begin{array}{c}20 \\
(13 \%) \\
\end{array}$ & $\begin{array}{c}15 \\
(10 \%) \\
\end{array}$ & $\begin{array}{c}2 \\
(1.3 \%) \\
\end{array}$ & 4.16 & 6 \\
\hline $\begin{array}{l}\text { Lack of motivation among } \\
\text { employees }\end{array}$ & $\begin{array}{c}63 \\
(42 \%) \\
\end{array}$ & $\begin{array}{c}37 \\
(24.67 \%) \\
\end{array}$ & $\begin{array}{c}30 \\
(20 \%) \\
\end{array}$ & $\begin{array}{c}19 \\
(12.67 \%) \\
\end{array}$ & $\begin{array}{c}1 \\
(0.67 \%) \\
\end{array}$ & 3.95 & 8 \\
\hline $\begin{array}{l}\text { Lack of government strict } \\
\text { regulation for Green ICT }\end{array}$ & $\begin{array}{c}120 \\
(80 \%)\end{array}$ & $\begin{array}{c}17 \\
(11.33 \%) \\
\end{array}$ & $\begin{array}{c}9 \\
(6 \%) \\
\end{array}$ & $\begin{array}{c}3 \\
(2 \%) \\
\end{array}$ & $\begin{array}{c}1 \\
(0.67 \%) \\
\end{array}$ & 4.68 & 1 \\
\hline $\begin{array}{l}\text { Lack of proper plan for green } \\
\text { ICT implementation }\end{array}$ & $\begin{array}{c}60 \\
(40 \%)\end{array}$ & $\begin{array}{c}45 \\
(30 \%)\end{array}$ & $\begin{array}{c}34 \\
(22.67 \%) \\
\end{array}$ & $\begin{array}{c}8 \\
(5.33 \%) \\
\end{array}$ & $\begin{array}{c}3 \\
(2 \%)\end{array}$ & 4.01 & 7 \\
\hline $\begin{array}{l}\text { No Budget allocation for } \\
\text { implementing green ICT }\end{array}$ & $\begin{array}{c}90 \\
(60 \%)\end{array}$ & $\begin{array}{c}30 \\
(20 \%)\end{array}$ & $\begin{array}{c}20 \\
(13.33 \%)\end{array}$ & $\begin{array}{c}10 \\
(6.67 \%) \\
\end{array}$ & $\begin{array}{c}0 \\
(0 \%)\end{array}$ & 4.33 & 5 \\
\hline $\begin{array}{l}\text { Indifferent for ICT workshops } \\
\text { to update knowledge }\end{array}$ & $\begin{array}{c}110 \\
(73.33 \%) \\
\end{array}$ & $\begin{array}{c}28 \\
(18.67 \%) \\
\end{array}$ & $\begin{array}{c}6 \\
(4 \%) \\
\end{array}$ & $\begin{array}{c}5 \\
(3.33 \%) \\
\end{array}$ & $\begin{array}{c}1 \\
(0.67 \%) \\
\end{array}$ & 4.61 & 2 \\
\hline $\begin{array}{l}\text { Lack of skilled or trained } \\
\text { manpower }\end{array}$ & $\begin{array}{c}100 \\
(66.67 \%) \\
\end{array}$ & $\begin{array}{c}28 \\
(18.67 \%)\end{array}$ & $\begin{array}{c}16 \\
(10.67 \%)\end{array}$ & $\begin{array}{c}4 \\
(2.67 \%) \\
\end{array}$ & $\begin{array}{c}2 \\
(1.33 \%) \\
\end{array}$ & 4.47 & 3 \\
\hline $\begin{array}{l}\text { Lack of research \& } \\
\text { development activities }\end{array}$ & $\begin{array}{c}90 \\
(60 \%) \\
\end{array}$ & $\begin{array}{c}40 \\
(26.67 \%) \\
\end{array}$ & $\begin{array}{c}14 \\
(9.33 \%) \\
\end{array}$ & $\begin{array}{c}5 \\
(3.33 \%) \\
\end{array}$ & $\begin{array}{c}1 \\
(0.67 \%) \\
\end{array}$ & 4.42 & 4 \\
\hline
\end{tabular}

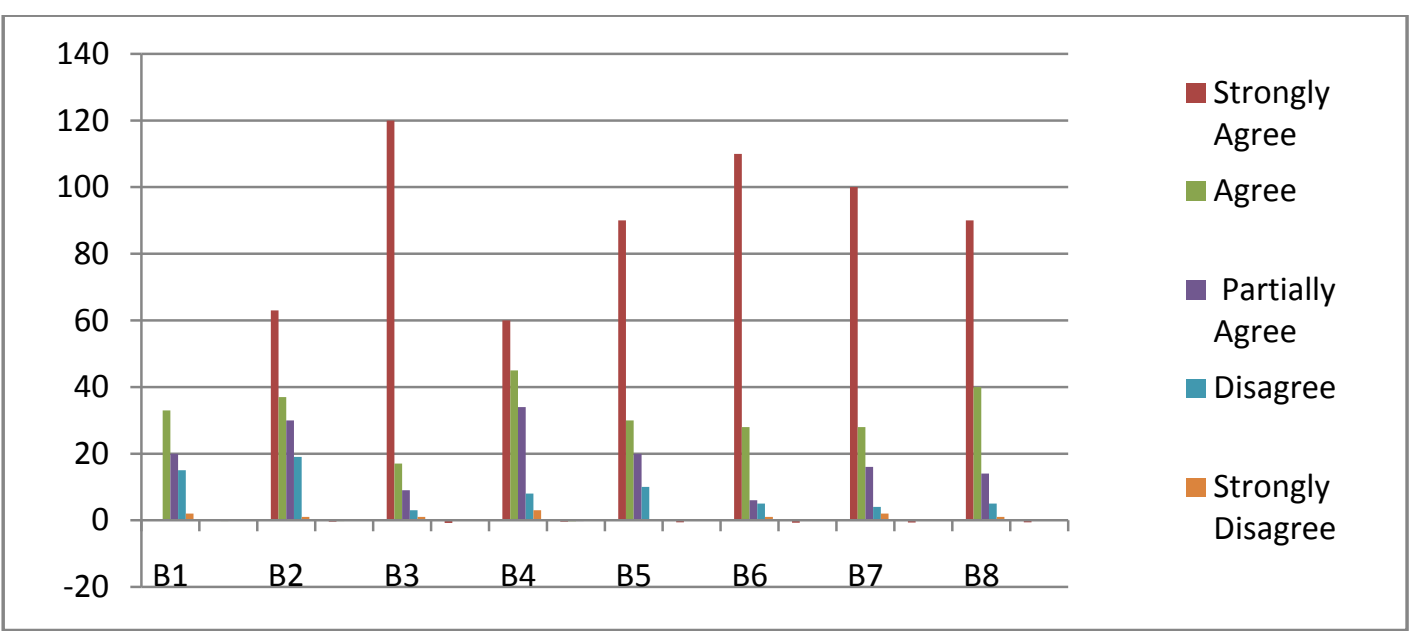

Fig. 1: Opinion of all respondents regarding barrier of Green ICT

ICT workshop describes the steps and methodologies leading to the briefing, organization and reporting of the Green ICT. It helps to understand about different forms of Green ICT. The study shows that 73.33 percent respondents are strongly opined that indifferent to arrange workshop on Green ICT is the obstacle for its implementation, whereas 66.67 percent strongly agree that lack of skilled and trained manpower is the reason behind the hurdle of Green ICT implementation at organization. The rank order comparison indicates that Lack of government strict regulation for Green ICT is the extreme barrier for implementation of Green ICT.

\subsection{Testing of Hypothesis}

To test above mentioned hypothesis considering barriers together, the researcher has considered the score of each respondent on barriers. Here, under null hypothesis the score needed to be three or less and under alternative hypothesis the score need to be greater than three. The statistical hypothesis corresponding to the above hypothesis with all barriers together is stated as:

$\mathrm{H}_{0}$ : The average score is three.

$\mathrm{H}_{1}$ : The average score is greater than three.

To decide whether to use parametric or non-parametric test, there is needed to test the average opinion of the respondents. This test is used to check whether the score of respondents is 
on average three or over. This test is parametric test and as the size of the respondents is over 30 , so the test is normal test. The result of the test is analyzed by SPSS, using one sample ttest. The tabulated result is shown below in the table 3 .

As P-value of the test is less than 0.05, here null hypothesis $\mathrm{H}_{0}$ is rejected and it can be said that the average score of all the barriers in the study is greater than three. This implies that, their agreements on mentioned barriers in implementation of GICT are statistically significant. Hence, the above mentioned hypothesis is validated and tested. From the above discussion it can say that the above factors are the barriers to implement green ICT in the organization

\section{Table 3: Result of t-test}

\begin{tabular}{|l|c|c|c|c|}
\hline \multicolumn{1}{|c|}{ Barriers to implement Green ICT } & $\mathbf{N}$ & t-value & p-value & Decision \\
\hline $\begin{array}{l}\text { Lack of update knowledge of rapid } \\
\text { changes of technology }\end{array}$ & 150 & 13.14 & 0.00 & Reject H0 \\
\hline Lack of motivation among employees & 150 & 10.62 & 0.00 & Reject H0 \\
\hline $\begin{array}{l}\text { Lack of government strict regulation } \\
\text { for Green ICT }\end{array}$ & 150 & 28.14 & 0.00 & Reject H0 \\
\hline $\begin{array}{l}\text { Lack of proper plan for green ICT } \\
\text { implementation }\end{array}$ & 150 & 12.17 & 0.00 & Reject H0 \\
\hline $\begin{array}{l}\text { No Budget allocation for } \\
\text { implementing green ICT }\end{array}$ & 150 & 17.26 & 0.00 & Reject H0 \\
\hline $\begin{array}{l}\text { Indifferent for ICT workshops to } \\
\text { update knowledge }\end{array}$ & 150 & 25.35 & 0.00 & Reject H0 \\
\hline Lack of skilled or trained manpower & 150 & 19.99 & 0.00 & Reject H0 \\
\hline $\begin{array}{l}\text { Lack of research \& development } \\
\text { activities }\end{array}$ & 150 & 20.57 & 0.00 & Reject H0 \\
\hline
\end{tabular}

\section{CONCLUSION}

Investment in environmentally sustainable ICT is the key to future success. A developing number of ICT sellers and clients are moving towards the green ICT and in this manner helping with building a green society and economy. At the point when organizations are looked with more green charges and direction, they will support green ICT arrangements.

Nowadays, world is facing multiple crisis and challenges that are mutually interlinked. Efforts should be made so that ICT leads by example and reduces the energy it uses in organizations. This study considered eight barriers to implement Green ICT in organization. Among the barriers the respondents opined that lack of Government strict regulation act is the main barrier for eco-friendly ICT implementation. The study also suggest for more of improving on the quality of the ICT technical human resource and training program. Moreover, the study recommends special budget allocation for improvement of green environment related technology. Most of the barriers identified are people dependent and hence for green ICT implementation to be accelerated.

So as to use the new ICT innovation, an organization should know about the items they are purchasing. Focusing on things like the vitality funds hardware alongside the general parts of a computer can help to extraordinarily decrease the measure of power utilized on an everyday premise. Replacing the old hardware with new and more proficient gear is just successful if the productivity distinction is high and the old equipment can be recycled or reused instead of simply ending up in a landfill.

'Being Green' should be understood as a long commitment that solves the motivation behind making a greener and economical foundation. Numerous organizations have just begun showing figures of the money they have saved in a schedule year by receiving practical greener techniques. Organizations which are new to 'Being Green' should look for the assistance of such effective models to set up a rundown of measures that are most fitting for their particular. Moreover, the results of this study can be used by top decision maker of the organization as a roadmap for friendly environment. Furthermore, they can use the specific determinants identified with the strategies of the organization to adopt decisions on the implementation of green ICT. It is important to note that the results of green ICT adoption are not immediate, both financial and those relating to environmental benefits. Therefore, beyond the rational factors, values of motivations of organizational top decision maker are very important in adopting green ICT.

\section{REFERENCES}

[1] Chai-Arayalert, S. \& Nakata, K. (2011). The Evolution of Green ICT Practice: UK Higher Education Institutions Case Study. IEEE International Conference on Green Computing and Communications, United Kingdom, pp 220-225.

[2] Yang, J., Han, Q., Zhou, J., \& Yuan, C. (2015). The Influence of Environmental Management Practices and Supply Chain Integration on Technological Innovation Performance - Evidence from China's Manufacturing Industry. Sustainability, 7, 15342-15361.

[3] Stark, N., \& Connolly, D. (2011). Green IT: part 2 technology and E-business series.

[4] Poritt, J. (2010). Green IT a global benchmark. A report on sustainable IT in USA, UK, Australia and India. Fujitsu, Australia.

[5] Ghose A., Hassan H. \& Spedding T. (2008). Carboncentric computing: IT solutions for climate change, University of Wollongong working group on the carboncentric computing initiative.

[6] Haung, L. K. (2012). Factors affecting green IT alignment: A contingency perspective. Business and Information. 3-5.

[7] Dedrick, J. (2010). Green IS: Concepts and issues for information systems research. Information Systems Management, 25(2): 159-173.

[8] Herman, H., Shalaby, B. R., \& Bundgen, R. (2010). The greeing of Business. Frankfurt: Am Main: International GmgH. 
[9] Njeru, K. M., Wachira, J. K., Geoffrey, M., Wanyembi, G., \& Waiithaka, S. (2014). An investigation on the applicability of Green IT concepts into Green IS. International Journal of Application or Innovation in Engineering and Management (IJAIEM), 3, 12, 198-204.

[10] Oecd Organisation for Economic Co-operation and Development (2009). Towards Green ICT Strategies: Assessing Policies and Programmes on ICT and the Environment.

[11] Fernando, P. \& Okuda, A. (2009). Green ICT: A cool factor in the wake of multiple meltdowns. Xuan Zengpei, Place, ESCAP technical paper.
[12] Henretig, J. (2011). Reduce CO2 emissions with UC tools. Microsoft news and resources, 28th April 2011 available at www.microsoft.com/environment/news access on 10 May 2011.

[13] Radu, L.D. (2016). Determinants of Green ICT Adoption in Organizations: A Theoretical Perspective. Sustainability, 8, 731 .

[14] Jan, R. (2016). Toward A Design Theory for Green Information Systems. 49th Hawaii International Conference on System Sciences, 4474-4483. 